\title{
RELATION BETWEEN LEARNING APPROACHES OF CHEMISTRY STUDENTS AND THEIR ACHIEVEMENT IN GENERAL CHEMISTRY
}

\author{
Stanislava Olić Ninković*, Jasna Adamov, Ljiljana Vojinović Ješić \\ Faculty of Sciences, University of Novi Sad, Serbia \\ stanislava.olic@dh.uns.ac.rs
}

\begin{abstract}
This research was conducted with the aim of investigating the relationship between students' approaches to learning chemistry and their levels of achievement. The sample was comprised of 46 students in the first year of the Faculty of Sciences in Novi Sad (Serbia). The research involved two instruments: a knowledge test and an instrument for assessing the learning approach. The results showed that students have difficulties in understanding the factors that influence the chemical equilibrium, as well as with writing equations of the chemical reaction of salt hydrolysis. Most students use a deep approach to learning chemistry content. The deep approach significantly correlates with student achievement. On the basis of these results, it is concluded that is important to create a climate in the classroom that will encourage a deep approach to the study of chemistry.
\end{abstract}

Key words: chemistry education; achievement; learning approach; students

\section{МЕЃУСЕБНА ЗАВИСНОСТ НА ПРИСТАПОТ НА СТУДЕНТИТЕ ПО ХЕМИЈА КОН УЧЕЊЕТО И НИВНИТЕ ПОСТИГНУВАЊА ПО ОПШТА ХЕМИЈА}

Целта на ова истражување беше да се испита меѓусебната зависност на приодот на студентите кон учење хемија и степенот на нивните постигнувања. Предмет на испитувањето беше група од 46 студенти од прва година на Природно-математичкиот факултетот во Нови Сад (Србија). Во истражувањето се користеа два инструмента: тест по знаење и процена на приодот кон учењето. Резултатите покажаа дека стуентите имаат тешкотии при разбирањето на факторите што влијаат врз хемиската рамнотежа, како и при пишувањето на равенки на хемиските реакции на хидролиза на соли. Многу студенти применуваат темелен пристап кон учењето на хемиските содржини. Темелниот пристап значително корелира со постигнувањето на студентот. Врз основа на овие резултати, заклучуваме дека е важно во училницата да се создаде клима што ќе го поттикне темелниот пристап за учењето хемија.

Клучни зборови: образование по хемија; постигнување; приод кон учењето; студенти

\section{INTRODUCTION}

What makes lipstick red? Which food should I eat when I am doing intense physical activity? How do you make cheese? What gives strawberries their fragrance? These and many more questions can be answered with chemistry. Chemical knowledge is indispensable to every individual because chemistry is everywhere around us: in food, water, clothes, drugs, cosmetics, hygiene, fuel and many other items.
Despite the fact that chemical knowledge is necessary for all of us, chemistry is often considered one of the most difficult school subjects and one of the subjects for which students are least motivated to learn. Many years of research have aimed to identify the areas that are the most difficult for students to learn and understand. Both national and foreign research has shown that there are many difficulties in the study of chemical content for example, in the study of chemical equilibrium $[1-4]$, salt hydrolysis [4, 5] and oxidation- 
reduction reactions [6]. This paper therefore focuses on examining the chemistry issues that create learning difficulties for students, as well as examining one of the possible factors that influences learning outcomes and achievement - namely, the learning approach.

The concept of learning approaches stems from the ideas and research carried out by Marton and Saljo in Sweden, Entwistle and Ramsden in the United Kingdom and Biggs in Australia and Canada in the second half of the 20th century [7]. On the basis of their results, they concluded that students apply three different approaches to learning: surface approach, strategic approach and deep approach. Students who take the surface approach to learning are more likely to be superficial, focusing on memorizing the information needed to achieve the goal. Consequently, without integrating or seeking meaning in what they learn, these student focus on specific parts of the material. These students are extrinsically motivated, observe tasks as being externally imposed and are encouraged by fear of failure to learn. Students using the strategic learning approach are oriented toward achievement - that is, reaching the goal and getting good grades. When learning, these students find optimal learning conditions and invest as much effort as they deem necessary to achieve the set goal. Intrinsic motivation is characteristic for students who approach learning in depth. These students are focused on understanding and linking ideas, oriented toward learning in which they see personal interest and satisfaction [8].

Access to individual learning depends on a large number of factors that can be explained using the 3P model: Precondition - Process - Product [9]. Preconditions are student-related factors (previous knowledge, skills and preferred learning approaches) and context-related factors (content of teaching, teaching and assessment methods and teaching environment and procedures). The process represents learning-oriented activities, that is, contemporary teaching approaches, and the product consists of learning outcomes, including quantitative (facts and skills) and qualitative outcomes (structure and transfer) and contextual approaches to learning. Since all the factors within the model are in interaction, they form a dynamic system. Based on the approach students use in learning, conclusions about the quality of teaching can be carried out, so a significant amount of research is focused on examining the different ways learners learn and their connection to learning outcomes.

The research carried out by Baeten and colleagues [10] examined the correlation of the role of teachers, contextual factors and personality traits of teachers with students' learning approaches. They concluded that the role of teachers is very important for the formation of a learning approach. If teachers are student-oriented and choose appropriate teaching strategies, students will be more inclined to take a deep approach. The mutual correlation between student learning approach and the role of teachers was confirmed in an earlier study by Gordon and Debus [11]. The research was carried out on a sample of future teachers, in which modifications of teaching methods and tasks were introduced. These modifications resulted first in a reduction of surface approaches and, later, in an increase in deeper learning approaches.

Concerning the perception of contextual factors, the results show that students who are satisfied with the course, the cognitive load, teaching methods and clarity of the set goals tend to take a deep approach to learning. It was noted that older students and students whose personality is characterized by openness, conscientiousness, conformity and emotional stability also approach learning in depth. Additionally, if students are essentially motivated and feel self-confident and self-conscious, they prefer teaching methods that support learning and understanding. More often, they will approach learning in depth [10].

As a result of the significant research interest in studying learning approaches, several questionnaires have been developed for their quantitative determination. The two most commonly applied questionnaires [11] for determining the approach to student learning in higher education are the questionnaires developed by Entwistle and Ramsden in 1983 (Approaches to Studying Inventory, ASI) and by Biggs in 1987 (Study Process Questionnaire, SPQ). In this paper, a modified version of the ASI questionnaire was applied: Approaches and Study Skills Inventory for Students, ASSIST: Tait, Entwistle and McCune [7].

Some empirical results indicate that a deep approach to learning is positively correlated with student achievement, whether achievement is assessed as an average annual grade or as achievement in a certain test of knowledge [12]. Chamorro-Premuzic and Furnham [13], in addition to the significant positive correlation between student achievements and the deep approach, have established the existence of a somewhat lower, positive correlation with the strategic approach, and no significant correlation with the surface approach.

In spite of the wide body of empirical research supporting the fact that the deep approach correlates positively with the achievement of students, there are arguments [14] that indicate a lack 
of relation between these two variables, while citing a significant negative predictor contribution of a surface approach and a positive contribution of a strategic approach.

Since the results of previous studies have not yet come to solid conclusions, in this paper, we wanted to examine the distribution of students' approaches to learning chemistry and their contribution to achievement in chemistry in order to derive practical implications from the obtained results.

\section{EXPERIMENTAL SECTION}

\subsection{Aim of the research}

The aim of the research was to examine the relation between students' approaches to learning and their achievements in chemistry. This research goal was operationalized through several research tasks related to examining student approaches to learning, assessing the achievements of students in a chemistry test, as well as examining the relationships among and contributions of the tested variables.

\subsection{Participants}

The sample included 46 students in the firstyear course in the Department of Chemistry at the Faculty of Natural Sciences and Mathematics in Novi Sad, enrolled in 2017/2018. The sample was formed in such a way that it provided an absence of interference factors, such as the influence of different professors. The sample included 13 (28.3 $\%)$ male students and $33(71.7 \%)$ female students. The age of the subjects was between 19 and 22 years $(\mathrm{M}=20.01, \mathrm{SD}=0.72)$.

\subsection{Instruments}

The questionnaire used to assess the individual learning approaches in students was the Approaches and Study Skills Inventory for Students (ASSIST) [12]. The applied questionnaire consists of 52 statements that describe characteristics and behaviors of students using deep, surface and strategic approaches to learning. The reliability coefficient of this questionnaire is 0.82 .

The achievement of students was estimated based on a knowledge test consisting of 10 items. The knowledge test includes general chemistry content that students from the Faculty of Natural Sciences and Mathematics in Novi Sad study during their first semester. Each correctly solved task was awarded with 3 points, and partially correct answers were also graded with the adequate number of points.

\subsection{Data analysis}

In statistical data processing, the basic descriptive indicators were calculated as well as the parameters for determining the basic psychometric characteristics of the applied instruments. In accordance with the research aims, the correlation coefficients of the tested variables were calculated. Regression analysis was applied to examine the contribution of the learning approaches to achievement in chemistry. Statistical data processing was performed using the IBM SPSS software package (version 21).

\section{RESULTS}

\subsection{Students' achievement in the general chemistry test}

The assessment of students' achievements in general chemistry was done using the knowledge test. Descriptive characteristics of the knowledge test show that distribution of results was found to be normal (skewness $=-0.25$; kurtosis $=-0.52$ ). The reliability of the test was checked by calculating Cronbach's $\alpha$. The value of this coefficient is 0.78 , indicating acceptable values [15]. The average score on the test was 19.43. The highest achieved score was 29.80 (the maximum possible score was 30 points), while the lowest score was 5 points. Table 1 shows the descriptive characteristics of individual tasks. It is interesting to note that the tasks with the lowest and highest scores belong to the same teaching topic - chemical equilibrium. Students were able to calculate the initial and equilibrium concentrations of participants in the chemical reaction, but did not understand how different factors affect the chemical equilibrium - that is, they do not understand Le Chatelier's principle. Students have also shown that they were able to name complex compounds based on chemical formulas, and vice versa, as well as write equations of chemical reactions in ionic form. Writing the equation of a salt hydrolysis reaction was a problem for them.

According to the criteria stated by Ding and colleagues [16], item difficulty index values in the range of 0.30 to 0.90 are considered acceptable, while 0.50 is considered to be the optimal value. The item difficulty indices in the applied knowledge test range from 0.30 to 0.83 , with a total test difficulty index of 0.65 . Based on these values, it is concluded that all items have acceptable values and that the entire test is of a moderate difficulty.

The indices of discrimination of items in the knowledge test range from 0.38 to 0.50 . A total of 90 $\%$ of the items have index values of more than 0.40 , 
which - according to the criteria stated by Ebel and Frisbie [17] - are classified in the category of tasks of excellent discrimination. Only one item has a slightly lower index of discrimination (0.38), and it is classified as an item with a good discrimination.
Based on the above parameters, it can be concluded that the applied knowledge test is reliable and has satisfactory characteristics. It can therefore be applied in further research.

Table 1

Descriptive characteristics of the knowledge test

\begin{tabular}{llcccc}
\hline \hline Item & \multicolumn{1}{c}{ Topic } & M & SD & $\begin{array}{c}\text { Difficulty } \\
\text { index }\end{array}$ & $\begin{array}{c}\text { Discrimination } \\
\text { index }\end{array}$ \\
\hline 1 & Chemical calculations & 2.01 & 1.14 & 0.67 & 0.40 \\
2 & Chemical calculations & 2.17 & 1.18 & 0.73 & 0.38 \\
3 & Chemical calculations & 1.87 & 1.41 & 0.63 & 0.47 \\
4 & Ionic reactions & 2.29 & 0.78 & 0.76 & 0.50 \\
5 & Redox reactions & 2.16 & 1.01 & 0.72 & 0.48 \\
6 & Reaction rate & 1.74 & 1.34 & 0.58 & 0.43 \\
7 & Chemical equilibrium & 2.47 & 0.93 & 0.83 & 0.46 \\
8 & Chemical equilibrium & 0.89 & 1.18 & 0.30 & 0.46 \\
9 & Chemical equilibrium & 1.54 & 1.13 & 0.52 & 0.53 \\
10 & Complex compounds & 2.27 & 0.61 & 0.76 & 0.49 \\
\hline \hline
\end{tabular}

Note. $\mathrm{M}$ - mean; $\mathrm{SD}$ - standard deviation

\subsection{Students' approaches to learning chemistry}

The applied Learning Assessment Questionnaire consists of three subscales that assess the distribution of the use of surface, strategy and deep approaches to learning. In the first step, the descriptive and psychometric parameters of the applied questionnaire were calculated (Table 2). Based on the value of the reliability coefficient of the individual subscales, skewness und kurtosis, it can be concluded that the applied instrument shows satisfactory characteristics.

Each of the above learning approaches was analyzed through multiple components. Surface access involves student perceptions about the purpose of learning, the content of the syllabus, the need to memorize materials and the fear of failure (Table 3).

Table 2

Descriptive and psychometric indicators of the ASSIST questionnaire

\begin{tabular}{lcccccccc}
\hline \hline Learning approach & $\mathrm{N}$ & Min & Max & $\mathrm{M}$ & SD & Sk & $\mathrm{Ku}$ & $\alpha$ \\
\hline Surface & 16 & 26 & 67 & 44.78 & 9.75 & 0.02 & 0.35 & 0.78 \\
Strategic & 20 & 39 & 98 & 73.17 & 12.43 & -0.55 & 0.35 & 0.87 \\
Deep & 16 & 41 & 80 & 61.04 & 9.31 & -0.17 & 0.36 & 0.85 \\
\hline \hline
\end{tabular}

Note. $\mathrm{N}$ - number of participants; Min - minimum; Max - maximum; M - mean; SD - standard deviation; Sk - skewness; $\mathrm{Ku}$ - kurtosis; $\alpha$ - cronbach's alpha coefficient.

Table 3

Representation of individual components of a surface approach to learning chemistry in first-year students

\begin{tabular}{lcc}
\hline \hline $\begin{array}{l}\text { Surface approach } \\
\text { component }\end{array}$ & $\mathrm{M}$ & $\mathrm{SD}$ \\
\hline Lack of purpose & 1.87 & 0.71 \\
Unrelated memorizing & 2.57 & 0.67 \\
Syllabus-boundness & 3.71 & 0.81 \\
Fear of failure & 3.06 & 1.08 \\
\hline \hline
\end{tabular}

Note. $\mathrm{M}$ - mean; $\mathrm{SD}$ - standard deviation
Of all the components of the surface learning approach, students least agree with claims that support the lack of the purpose of learning chemical content, as well as practicing memorizing facts without relating them to the previous knowledge. On the other hand, students stated that they are studying only from the literature that is necessary in order to pass the exam and those parts of the materials that they believe will be covered by the exam questions.

A strategic approach includes the perception of organizing learning, managing time, meeting assessment demands and focusing on student achievement and self-efficacy. 


\section{T a ble 4}

Representation of individual components of a strategic approach to learning chemistry in first-year students

\begin{tabular}{lll}
\hline \hline $\begin{array}{l}\text { Strategic approach } \\
\text { component }\end{array}$ & $\mathrm{M}$ & $\mathrm{SD}$ \\
\hline Organized studying & 2.87 & 0.67 \\
Time management & 2.63 & 0.85 \\
$\begin{array}{l}\text { Alertness to assessment } \\
\text { demands }\end{array}$ & 2.70 & 0.54 \\
Achieving & 3.34 & 0.51 \\
Monitoring effectiveness & 3.08 & 0.66 \\
\hline \hline
\end{tabular}

Note. $\mathrm{M}$ - mean; $\mathrm{SD}$ - standard deviation

Students mostly agreed with the statements that indicate their focus on achievement and monitoring effectiveness while solving tasks. There was an approximately equal amount of consensus among students relating to the organization of time, learning and the orientation to meeting the set requirements. The deep approach refers to seeking meaning, linking ideas, using data and interest in ideas (Table 5).

\section{Table 5}

\section{Representation of individual components of a deep approach to learning chemistry in first-year students}

\begin{tabular}{lll}
\hline \hline $\begin{array}{l}\text { Deep approach } \\
\text { component }\end{array}$ & $\mathrm{M}$ & $\mathrm{SD}$ \\
\hline Seeking meaning & 4.09 & 0.67 \\
Relating ideas & 3.86 & 0.66 \\
Use of evidence & 3.84 & 0.65 \\
Interest in ideas & 3.49 & 0.83 \\
\hline \hline
\end{tabular}

Note. $\mathrm{M}$ - Mean; SD - Standard deviation

Students have shown the highest agreement with statements that are characteristic of a deep learning approach, compared to the other two sub- scales. Students want to know the meaning of what they are learning and link new concepts with information they have already learned. They look at the evidence carefully and try to reach their own conclusion about what they are studying. They also find some topics exciting and truly gripping.

In the next step, an individual approach to the study of chemistry was determined for each student by comparing the arithmetic mean of the subscales. The results shown in Figure 1 indicate that more than half of the students $(56.5 \%)$ take a deep approach to learning chemistry, $34.8 \%$ take a strategic approach, while the least number of students $(8.7 \%)$ take a surface approach to learning chemistry.

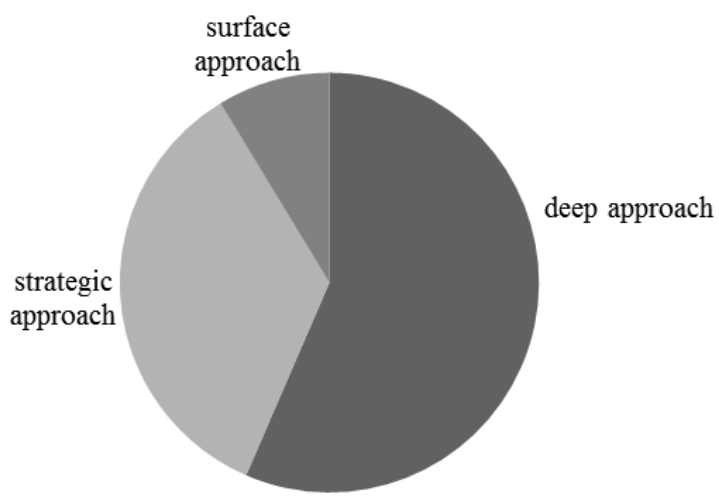

Fig. 1. Approaches to learning in chemistry students

\subsection{Correlation between learning approach and student achievement}

Students with different learning approaches have different achievements in general chemistry (Fig. 2). The results obtained are in line with expectations based on existing qualitative and quantitative research. The highest results are achieved by students who take a deep approach to learning chemistry, and the lowest results are achieved by students taking a surface approach.

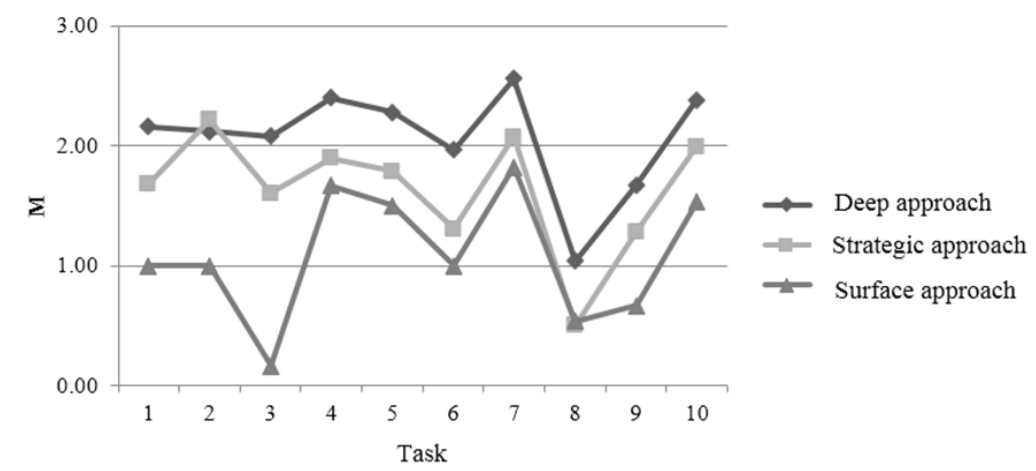

Fig. 2. Achievements of students taking deep, surface and strategic approaches to learning chemistry 
The observed correlation between the learning approach and the achievement of students in chemistry was examined by calculating the Pearson linear correlation coefficient (Table 6).

Table 6

Pearson coefficient of correlation between examined variables

\begin{tabular}{lc}
\hline \hline Variable & Achievement \\
\hline Surface approach & -0.08 \\
Strategic approach & 0.04 \\
Deep approach & $0.46^{* *}$ \\
\hline \hline Note. $* * * 0.01$ &
\end{tabular}

The obtained results show that student achievement positively correlates only with a deep approach to learning chemistry.

\subsection{Contribution of the learning approach to achievement in chemistry}

To fully understand the relationship between students' approaches to learning chemistry and their achievement, regression analysis was applied. The regression model in which learning approaches are predictors of achievements in chemistry is statistically significant $\left(\mathrm{R}=0.49 ; \mathrm{R}^{2}=0.25 ; \mathrm{F}(4\right.$, $90)=3.33 ; \mathrm{p}=0.02)$ and explains $25 \%$ the variance of achievement.

\section{Table 7}

Approaches to learning as predictors of achievements in chemistry

\begin{tabular}{lcc}
\hline \hline Learning approach & $\beta$ & $\mathrm{p}$ \\
\hline Surface approach & 0.10 & 0.39 \\
Strategic approach & -0.09 & 0.29 \\
Deep approach & 0.41 & 0.00 \\
\hline \hline
\end{tabular}

From the model of the predictor variables shown in Table 7, only the deep approach is distinguished as significant in predicting student achievement, and the direction of the contribution is positive. The strategic and surface approaches to learning have not proved to be significant predictors of achievements in chemistry.

\section{DISCUSSION}

The paper examines the approaches to learning the content of general chemistry and their con- tributions to predicting student achievement. In the first step, the descriptive and psychometric parameters of the applied instruments were analyzed. The results showed that the instruments are reliable, have satisfactory characteristics and can be used for research purposes.

By examining the results of the knowledge test, it was concluded that students have difficulty understanding the influence of different factors on the chemical equilibrium, that is, they do not understand Le Chatelier's principle, which has been observed in other national and international research $[1,2,3,4]$. Students have also shown that they have difficulty writing equations of salt hydrolysis, which has also been reported in other studies $[4,5]$. Although the results of foreign studies indicate that the writing of oxidation-reduction reactions creates difficulties for students [6], most of the students involved in this study have shown that they can successfully balancing the redox equation.

In this research, it was found that the majority of students study general chemistry content in depth. A smaller proportion of students learn chemistry strategically, and the smallest number of students use a superficial learning approach. In other words, for the majority of students the goal is acquiring skills and understanding material and relating it to previous knowledge, rather than memorizing and reproducing facts. This indicates that they understand the importance of the knowledge of basic chemical concepts for further learning of chemistry, and that the demands placed on them stimulate deep learning. Such results are particularly encouraging given the fact that students included in the study were first-year students, and according to Zeegers [12], older students are more inclined to have a deep approach and are more willing and able to devote themselves to learning strategies that require greater effort. Therefore, it can be expected that in the coming years, more students will acquire a deep learning approach. The fact that the majority of students studying general chemistry already takes a deep approach to learning profoundly reflects the positive image of the instructional methods used, since the teacher plays a very important role in developing a learning approach in their students [10]. The smallest number of students approaches learning chemistry in a superficial way, that is, new concepts are memorized without an essential understanding of content and without meaningful learning. This approach is also characterized by a pronounced fear of failure. One-third of the students learn chemistry in order to achieve the set goal, 
and they try to find optimal learning conditions in order to do so.

By linking the approach to learning and the achievements of chemistry students, the results obtained support the findings of previous research, which supports the existence of a positive correlation between student achievement and the deep learning approach [12]. However, the connection to the strategic and surface approach has not proved to be significant.

The regression model also showed that learning approaches explain $25 \%$ of the variance of students' achievements in general chemistry, where the only significant predictor is a deep approach to learning. This leads to a simple conclusion: The incentive of the deep approach increases the achievement of students in chemistry.

Although there are findings about the adaptability of learning approaches, Zeegers' study [12] states that the results obtained in intervention studies and the modification of learning approaches are not encouraging, and that modification is most effective in students with high cognitive abilities. Additionally, the modification of the learning approach must also include a change in the motivation for learning, because the affective domain is highly significant. The nature of the subjects and the teacher's demands, or the student perceptions of the teacher's demands, have an impact on the choice of learning strategies that they find most relevant to solving the tasks. If the teacher expects students to understand the material, students will adapt to the requirements and learn in such a way that deep understanding is cultivated and the material is related to existing knowledge. However, if the teacher poses questions that require only memorization, some learners, particularly those oriented toward achievement, will consider the memorization as an adequate learning strategy for achieving the goal (that is, to get high grades).

The results of this research have a theoretical contribution and significant practical implications. The theoretical contribution is reflected in supporting the results that confirm the existence of the relation between learning approach and student knowledge, since this study established a significant positive contribution of the deep approach to the achievement of students.

These findings have practical implications that show that in order to increase students' skills and to encourage the deep learning approach, it is necessary to use adequate teaching strategies, methods and forms of work. In addition, the chemical content that creates the most difficulty in learning and understanding was identified, and therefore, more attention should be devoted to teaching that specific material.

\section{CONCLUSIONS, LIMITATIONS AND IMPLICATIONS FOR FURTHER RESEARCH}

Based on the results obtained in this study, several conclusions can be drawn. Our research has identified the material that students have difficulty learning. This material primarily includes difficulties in understanding the factors that influence the chemical equilibrium (Le Chatelier's principle) and writing the equation of the chemical reactions of salt hydrolysis.

Furthermore, more than half the sample of chemistry students take a deep approach to learning chemistry, and these students also achieve the highest scores. Very few students take a surface learning approach.

The general conclusion is that learning approaches are a significant factor contributing to the achievement of chemistry students, and it is only the deep learning approach that has a significant positive contribution. Therefore, the intrinsic motivation of students; the study of educational content by linking it with existing knowledge and experience; and seeking clear meanings and understanding the studied concepts leads to higher academic achievements in chemistry. The findings of this research are relevant for educational practitioners and researchers, as they demonstrate that is important to encourage the development of a deep approach to learning chemistry content, as it is indeed related to student achievement. In addition, discovering the areas of general chemistry that lead to learning difficulties and that require more attention when teaching and learning is also an important finding.

One significant limitation of this study is related to sample size, caused by the number of firstyear students of chemistry at the University of Novi Sad. Thus, caution must be taken when generalizing the findings to other populations of chemistry students. Future studies should include a more heterogeneous group of participants from other universities in order to examine the relationship between students' approaches to learning chemistry and their achievements in detail. Secondly, the ASSIST questionnaire has shown satisfactory basic descriptive and psychometric properties, but an extensive study was not carried out to validate this instrument in the Serbian context. Therefore, future research needs to have a primary goal of validating this questionnaire in the Serbian language. 
Acknowledgements. This research was funded by the national project of the Ministry of Education, Science and Technological Development of the Republic of Serbia, No. 179010 (KOSSEP - Quality of the Education System in Serbia in the European Perspective).

\section{REFERENCES}

[1] J. H. Van Driel, W. Gräber, The teaching and learning of chemical equilibrium In: Chemical Education: Towards Research-Based Practice, J. K. Gilbert, O. de Jong, R. Justi, D. F. Treagust, J. H. van Driel (Eds.), Springer Science \& Business Media, 2002 pp. 271-292.

[2] K. W. Voska, H. W. Heikkinen, Identification and analysis of student conceptions used to solve chemical equilibrium problems, J. Res. Sci. Teach., 37, 160-176 (2000).

[3] V. Kind, Beyond appearances: Students' misconceptions about basic chemical ideas, Sch. Educ., 1-84 (2004). DOI:10.1017/CBO9781107415324.004.

[4] S. Olić, J. Adamov, The relationship between learning styles and students` chemistry achievement, Mac. J. Chem. Chem. Eng., 37, 79-88 (2018).

DOI: $10.20450 / \mathrm{mjcce} .2018 .1400$.

[5] K. Orwat, P. Bernard, A. Migdał-Mikuli, Alternative conceptions of common salt hydrolysis among uppersecondary-school students, J. Balt. Sci. Educ., 16, 64-76 (2017).

[6] O. de Jong, D. F. Treagust, The teaching and learning of electrochemistry in: Chemical Education: Towards Research-Based Practice, J. K. Gilbert, O. de Jong, R. Justi, D. F. Treagust, J. H. van Driel (Eds.), Springer Science \& Business Media, 2002, pp. 317-337.

[7] N. J. Entwistle, V. McCune, H. Tait, The Approaches And Study Skills Inventory For Students (ASSIST). Centre for Research on Learning and Instruction, University of Edinburgh, 1997.
[8] H. F. Gadelrab, Factorial structure and predictive validity of approaches and study skills inventory for students (ASSIST) in Egypt: A confirmatory factor analysis approach. J. Res. Educ. Psy., 9, 1197-1218 (2011).

[9] S. Mirkov, Pristupi učenju i ispitivanja delovanja sredinskih činilaca. Zbornik Instituta za pedagoška istraživanja, 41, 25-44 (2009).

[10] M. Baeten, E. Kyndt, K. Struyven, F. Dochy, Using student-centred learning environments to stimulate deep approaches to learning: Factors encouraging or discouraging their effectiveness. Educ. Res. Rev., 5, 243-260 (2010). DOI: 10.1016/j.edurev.2010.06.001

[11] C. Gordon, R. Debus, Developing deep learning approaches and personal teaching efficacy within a preservice teacher education context. Brit. J. Educ. Psy., 72, 483-511 (2002). DOI: 10.1348/00070990260377488

[12] P. Zeegers, Approaches to learning in science: A longitudinal study. Brit. J. Educ. Psy., 71, 115-132 (2001). DOI: $10.1348 / 000709901158424$

[13] T. Chamorro-Premuzic, A. Furnham, Personality, intelligence and approaches to learning as predictors of academic performance. Per. Ind. Diff., 44, 1596-1603 (2008). DOI: 10.1016/j.paid.2008.01.003

[14] A. Diseth, Ø. Martinsen, Approaches to learning, cognitive style, and motives as predictors of academic achievement. J. Educ. Psy., 23, 195-207 (2003). DOI: $10.1080 / 01443410303225$

[15] A. Field, Discovering statistics using SPSS, Sage, London, 2009.

[16] L. Ding, R. Chabay, B. Sherwood, R. Beichner, Evaluating an electricity and magnetism assessment tool: Brief electricity and magnetism assessment, Phys. Rev. Spec. Top. Phys. Educ. Res., 2, 1-7 (2006). DOI:10.1103/PhysRevSTPER.2.010105.

[17] R. Ebel, D. Frisbie, Essentials of Educational Measurement, Pretince-Hall of India, New Delhi, 1991 